\title{
Boissier and botany at Geneva: a historical note
}

\author{
(the late) G. Bocquet* \\ Conservatoire et Jardin botaniques, Case Postale 60, CH-1292, Chambésy-Genève, \\ Switzerland
}

Geneva's contribution to this meeting in Edinburgh is the publication of a booklet dedicated to Boissier (Burdet 1985) on the centenary of his death - an anniversary which coincides with the completion, or approaching completion, of a series of major studies on the floras of SW Asia covering much of the area of Boissier's classic Flora Orientalis.

The brochure is intended to commemorate 100 years of Boissier's posthumous influence over the study of the flora of the area. It also marks, perhaps with a certain degree of nostalgia, the end of an epoch. Much has already been written, some of it very good, about Boissier. It was therefore self-evident that a genuinely original text could not be produced. Even the Geneva archives, though very extensive, did not offer anything new except anecdotes or side-lines on his life; details, for instance, of Boissier as a Protestant zealot, as active in this capacity as he was a botanist. We therefore preferred to collate a few texts which are certainly known, but which are excellent and rather difficult to find. With his usual talent, Mr H. M. Burdet undertook their selection. There are contributions from, or extracts from the writings of, G. Bocquet, J. I. Briquet, H. M. Burdet, F. Chodat, H. Christ, A. P. de Candolle, B. P. G. Hochreutiner and M. Mermoud.

Geneva, more than many similar institutions, was born round its herbaria, rather than its gardens. The Conservatoire Botanique is certainly the repository of a tradition which is at the same time authentically Genevan and highly classical. This tradition is of course very conservative. Often falling back on collection, it has sometimes found it difficult to accept new developments such as ecology, associations, cytology, chemical, genetic and molecular science. A prevalent idea has always been, in fact, that the noble collections entrusted to the Genevan botanists were an instrument in themselves. The presence of this instrument was sufficiently rare and exceptional to demand total and exclusive dedication to the collection as a tool. Yet the world is changing as the needs of mankind evolve. Botany is itself undergoing a transformation which Geneva cannot ignore. It seems to me that the recent history of the Conservatoire and Jardin botaniques may take on a more general interest. Why these changes, which are profound and diverse, in an institution which seems so rich that it should be self-sufficient? Is it a modernist craze, or a strategy for survival? Is it the necessity of our time, or the pursuit of fashion?

For A. P. de Candolle and his successors, the herbaria were the support of a fundamental research into systematics. The gardens, for their part, were a practical *Professor Bocquet died suddenly on 28 July, 1986. 
necessity, a place for teaching, and as much as in the case of Kew or Berlin, what we would call today an "experimental station", intended to promote the introduction of new varieties. In a certain sense, one might say that in the Geneva tradition the gardens, though highly appreciated by the local population, were a secondary creation and an accessory. This was true to such an extent that, until a few years ago, the institution never had a department serving the general public or publications intended for the general public. Laboratories and experimental plots were constantly neglected, for the sake of a traditional research essentially directed towards the library and the herbarium, often even ignoring field-work. Until a few years ago the gardens never had a catalogue, or even a system for recording acquisitions, let alone a collection of maps; there is still a lack of experimental plots and hot-houses. These shortfalls can be understood if one considers the nature, the content and the influence of Candolle's and Boissier's collections. They give a practical form to genuine philosophies of work.

Candolle's herbarium is little concerned with variation, whether individual or seen in its geographical context. In one sense, it is too old-fashioned. But above all, what Candolle and his followers sought, as systematists, was to "cover the ground": they were sometimes satisfied with fragments, so long as many species were represented. They acquired (rather than harvested) as many "items of information" as they could: the system was all that mattered, and it had to be as complete as possible.

Boissier, for his part, was a pioneer of floristics. He was interested in variation and one finds, in his names for species, a fine collection of chorological epithets; in this context it is worth noting that in his lifetime he described almost 6000 new species. Boissier was often able to grow, in Geneva or in Valleyres, the progeny of plants collected in the course of his travels. What has been entrusted to modern botanists is the material evidence of a Titan's labours, the calibration standards of monumental works, fixed for all time. This is true to such an extent that I recall, from my early days as a botanist in the fifties, an uninterrupted flow of botanists coming from the whole world over to work in Geneva or to ask for loans. In the case of the Boissier herbarium, this current started from the time the botanist died and his collection gained "historic" status. A small stream at first, it reached its flood peak after the last war. It is quite clear that, at that time, the application of the rules of nomenclature, which had become universal and mandatory, made these pilgrimages to Geneva essential. For us Genevans, these visits were stimulating and fascinating. Implicit devotion to foreign colleagues, however, made heavy inroads into the precious time earmarked for research. Above all, there was a danger of growing complacent and drowsy, through basking in the glory of these venerable collections, and of being tempted to feel excessively important. The curator's job became a priesthood and, combined with the well-known dogma of academic freedom, it was liable to become a pillow for the lazy. Hence we ignored the realities of an increasingly fast-moving world. In other words, we have to remind ourselves of Grime's triangle: an institute which has not enjoyed such generous largesse from the past remains competitive: a historical museum joins the "stress" pole, confined in its ivory tower.

We still have visitors in Geneva, of course, but they are fewer. They are coming increasingly for taxonomic work, and tend to be associated with our own scientific activity rather than with the historical value of the collections. Recent harvests, less well known, but very complete, such as John Briquet's, are a new focus of interest. 
This shift is easily explained, since the greater part of the work on nomenclature has been completed or is nearing completion. The facilities of modern documentation also play their part.

This comparative oblivion is of course less pronounced in the case of the Boissier herbarium, since the collection is more recent and Boissier, as an outstanding forerunner, understood the importance of species variability. Beyond its historical value, the Boissier herbarium retains its major taxonomic interest, and remains an important source of biological information. Needless to say, this remark is particularly relevant for studies on the floras of SW Asia and Spain. Nevertheless, the solemn gates of the great monuments are closing on the old Genevan herbaria, majestically but relentlessly.

Through the effects of chance, the consequences of the post-1974 crisis are being felt in Geneva too. Switzerland is said to be a rich country, and this is true up to a point, but we must not forget that the country is small, without natural resources, and that 150,000 Genevans support the Conservatoire and Jardin botaniques among several other cultural institutions. The Genevan botanical collections therefore cannot be expected to keep on growing. On the other hand, the loyalty of the Genevans to their scientific and especially their botanical past, and to their museums, is real and effective. They are proud of the research they subsidise, but at the same time they will not agree that the Jardin botaniques should confine itself to the role of a historical curiosity shop. The time has therefore come to set ourselves new objectives, to recast strategies: it is a time for imagination and for creation.

There is, of course, no question of forgetting or of neglecting the precious heritage of the past, and we will continue to protect and to make the most of the Genevan collections. On the other hand, we shall have to find new solutions, to weave lasting links with the University, to attract the students who come to be taught there, and fill them with enthusiasm. It will be necessary, for instance, to allow more scope for applied research, the research that makes it possible to be useful and to "place" one's students; the study of weeds; reafforestation; green spaces and horticulture. An effective and computerised floristic programme, including the garden in its regional context, should make it possible, through a data base, to achieve better knowledge of flora and of its evolution. On a technical plane, the computer must supply new "tools" for inventories, the reduction of texts (micro-filing), cartography and the management of collections - and also for contacts with the general public.

Finally, part of the new success will depend on the influence that the institution can bring to bear on the environment. The general population is under the impression, largely justified, of living through dangerous times in a dangerous world. It must be able to count on the institutions which it supports, including botanical institutions. It is therefore a revolution that is beginning, not only for Geneva but for other traditional herbaria and gardens, at the very time when historic values are becoming blurred. We will have to find a way to live through these changes while maintaining our respect for the traditions established by de Candolle and Boissier.

\section{Reference}

Burdet, H. M., ed. 1985. Edmond Boissier, Botaniste genevois 1810-1885-1985. Genève: Editions des Conservatoire et Jardin botaniques de la Ville de Geneve; série documentaire 17. 